\section{Introducing biology}

\section{E.C. Cox \& R.M. May}

Exploring Biology, 2nd Edn.

By Pamela S. Camp and Karen Arms.

Holt Saunders/Holt, Rinehart \&

Winston: 1984. Pp.591. f27.95, \$32.95.

Bioscope, 2nd Edn.

By Thomas A. Easton and

Carl E. Rischer.

Charles E. Merrill: 1984. Pp.719. Hbk

f16.95; pbk \$19.95.

Biology: The Unity and Diversity of Clfe, 3rd Edn.

By Cecie Starr and Ralph Taggart.

Wadsworth: 1984. Pp.697. \$29.10,

£49.60.

Biology: An Introduction.

By Kenneth D. Johnson, David L. Rayle

and Hale L. Wedberg.

Benjamin/Cummings: 1984. Pp.615.

$\$ 28.95$, £25.15.

ALL four of these texts are intended for students who will probably take only one biology course and whose teachers are interested in covering the broad range of topics now typically found in standard texts for science majors. Three of them follow what many have come to accept as the preordained little-to-big (molecules to ecology) order of presentation. The exception is Camp and Arms (CA), whose book begins with evolution and ecology, and then proceeds to cells, genetics, plants and animals; this book is essentially a scaleddown version of the same authors' Biol$o g y$, a well-written text for science majors.

With the exception of Easton and Rischer (ER), which has an unfortunate number of errors, these books are scholarly, accurate, up-to-date and well produced - Starr and Taggart (ST) exceptionally so - , including thorough coverage of plant biology, and good discussions of human anatomy and physiology. Although intended for a one-term survey course, they treat the readers seriously, something we found lacking in similar texts when we reviewed this field several years ago. The books have a seriousness of purpose and intellectual rigour that is easily lost when authors try too hard to enliven their subject by making it trendy and "relevant" (and even here there remain lapses from grace, such as the photo in Johnson, Rayle and Wedberg (JRW) captioned "the rock star Johnny Winter is an albino"').

ST is an extraordinarily well illustrated book, with figures and photographs that rival those in Curtis's Biology for clarity and sheer beauty. The other three books are illustrated well, but none comes close to ST. All the books end each chapter with review questions and a list of suggestions for further reading. These lists are a bit dated, idiosyncratic and exhibit the usual high coefficient of inbreeding with other introductory texts.

The evolution and ecology sections do not strike us as the strongest parts of any of the four books. In this respect, none of them is up to the standards set by Purves and Orians in Life: The Science of Biology. There are, however, interesting differences among the four. JRW and ER illustrate speciation with the rather tired example of the beaks of Galapagos finches; CA uses the more compelling example of the Hawaiian honeycreepers; ST also uses the Hawaiian honeycreepers, but with an illustration that is more complete and more beautiful than that of CA. All four books discuss continental drift and its relation to past and present biogeographical patterns, but while the other three show the usual picture of continental drift over the past 200 million years, ST have a new doublepage spread correlating the evolution of life with the location of the continents since the late Cambrian (540 million years ago). On the other hand, ST is the only one of the books to perpetuate the appealing but incorrect generalization that roughly $10 \%$ of the energy at one trophic level is transferred to the next (it is one of our pet peeves that this "law" is so long in dying). On balance, however, ST seems to have

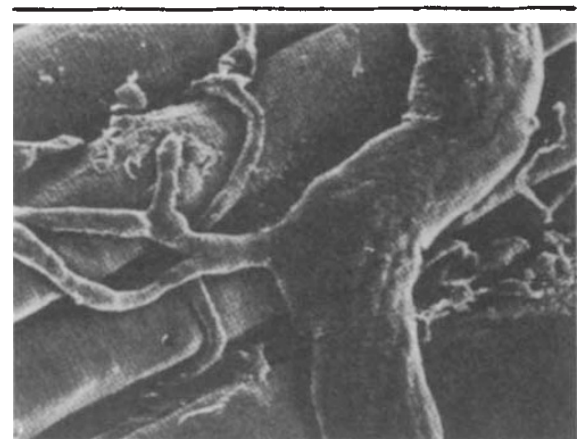

Nerve fibres on muscle $(x 900)$. The picture is taken from Biology by Claude Villee et al., published by Holt Saunders/Holt, Rinehart \& Winston.

made the greatest efforts to break out from the incestuous patterns - the convergence in use and reuse of familiar examples that afflict most introductory texts.

All the books make efforts to incorporate recent advances, going beyond the molecular biology of the gene to the molecular biology of the cell. But the text fully bringing an abstract of Alberts et al. 's Molecular Biology of the Cell into the introductory classroom remains to be written.

More generally, it seems that if an elementary text is to give some idea of the great diversity of methodology and levels of analysis currently found in the biological sciences, it must sacrifice something in the telling. In the books reviewed here, what is lost is a feeling for the way in which science is done and for the elegance of many experiments. It seems to us that this is inevitable in a non-trivial book for a oneterm course, where the emphasis is on scientific content. Whether or not this is how non-science majors should be taught has always been a matter for lively debate, and could well be the subject of a different essay.

None of these books spends more than a sentence or two on creationist theories. Only JRW includes a reference in the index, and the authors briefly and sensibly say that all such conjectures are matters of faith outside the realm of science. This represents a change in college texts over the past several years. Not long ago authors felt compelled to defend Darwinism against attacks from modern proponents of special creation (with Luria, Gould and Singer's $A$ View of Life being a high-water mark). Happily, this is no longer so if these texts are at all representative. The poverty of special creation theories as scientific explanation is taken as given.

Broadly speaking, the intrusion of the social and moral concerns of textbook writers into purportedly objective texts must surely date from earliest times. In this respect the books under review also represent a change from recent crops, in that they mainly focus on science, tending to leave out issues that always have seemed to us more properly contained in social science texts. No doubt there will continue to be introductory texts on the market that grip the student with rhetorical pleas for the state of the environment or the brotherhood of man (or siblinghood of persons), but these are not among them. There are lapses, such as ER ending with the timehonoured two views of the future (replete with imaginative illustrations of how "the movement to space could begin with the construction of orbiting space colonies'), but in the main we have factual accounts that balance the many disciplinary calls on the student's attention with the need to remain comprehensive and easy to read.

All in all, we think ST comes out ahead. CA and JRW are both good, with JRW deliberately aiming a bit higher (for example, it gives the mathematics of the Hardy-Weinberg law, while CA does not). ER is pitched a bit lower than the other three, and contains quite a few serious errors and misleading figures: for instance, on page 115 the two polynucleotide chains of the double helix have the same polarity, while the codon table on page 117 is badly scrambled. We like ST best because it is so well illustrated, succinct and marvellously clear. It also manages to cover more ground and to do the best job of the three in the sections on energetics and chemistry, while retaining its comprehensiveness and avoiding excessive length and detail.

Personal preferences notwithstanding, all but ER are good value. This may in part be because the authors have worked closely with their reviewers, as acknowledged in each preface. The majority of the reviewers involved have wide experience teaching the students for whom the books are written. All of us profit from this collaboration. $\square$

Edward C. Cox and Robert M. May are Professors in the Department of Biology at Princeton University. 